IJIF

11,1

98

Received 16 October 2017 Revised 6 March 2018 31 December 2018

30 January 2019

Accepted 31 January 2019

\section{A proposed human resource management model for zakat institutions in Malaysia}

\author{
Aznan Hasan, Rusni Hassan and Engku Rabiah Adawiah Engku Ali \\ Institute of Islamic Banking and Finance (IIBF), \\ International Islamic University Malaysia, Kuala Lumpur, Malaysia \\ Engku Muhammad Tajuddin Engku Ali \\ Universiti Sultan Zainal Abidin (UniSZA), Kuala Terengganu, Malaysia \\ Muhamad Abduh \\ School of Business and Economics (UBDSBE), Universiti Brunei Darussalam, \\ Gadong, Brunei Darussalam, and \\ Nazrul Hazizi Noordin \\ International Centre for Education in Islamic Finance, Kuala Lumpur, Malaysia
}

\begin{abstract}
Purpose - The purpose of this study is to propose a contemporary human resource management (HRM) framework by zakat institutions, which collect and manage religious alms, both obligatory (zakat) and voluntary (sadaqah), in Malaysia.

Design/methodology/approach - In doing so, discussions pertaining to the key elements of zakat institutions' HRM including recruitment, selection, performance appraisal, training and development and compensation are gathered from the existing literature and other sources of information such as zakat institutions' websites and publications. In addition, zakat officers' insight on how HRM is practiced at their institutions is gathered through a series of semi-structured interviews and incorporated in the findings of this study.

Findings - The paper finds that the state government, by virtue of the State Islamic Religious Council (SIRC), which is the sole trustee of all waqf properties in Malaysia, may have significant influence in formulating the human resource strategies and policies in zakat institutions.

Research limitations/implications - The proposed HRM model can be a useful reference for SIRC in enhancing the current human resource practice in its respective zakat institutions.

Originality/value - The novelty of this study lies in the proposed HRM model applicable to zakat institutions. The model emphasizes the alignment between the zakat institutions' HRM practice and their zakat collection and distribution goals, as well as zakat management objectives in general.
\end{abstract}

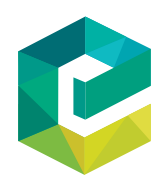

Keywords Zakat, Human resource management, Human capital, Malaysia

Paper type Conceptual paper

(C) Aznan Hasan, Rusni Hassan, Engku Rabiah Adawiah Engku Ali, Engku Muhammad Tajuddin Engku Ali, Muhamad Abduh and Nazrul Hazizi Noordin. Published in ISRA International Journal of Islamic Finance. Published by Emerald Publishing Limited. This article is published under the Creative Commons Attribution (CC BY 4.0) licence. Anyone may reproduce, distribute, translate and create derivative works of this article (for both commercial and non-commercial purposes), subject to full attribution to the original publication and authors. The full terms of this licence may be seen at http://creativecommons.org/licences/by/4.0/legalcode
ISRA International Journal of Islamic Finance pp. $98-109$ Emerald Publishing Limited 0128-1976

DOI 10.1108/IJIF-10-2017-0036 Vol. 11 No. 1, 2019 


\section{Introduction}

Human resource management (HRM) is a vital internal function of an organization that helps to ensure effective use of human capital in achieving the organizational objectives. Analyzing the impact of HRM policies and practices on an institution's performance is a crucial topic of discussion in modern organizational management (Boudreau, 1991; Jones and Wright, 1992). As argued by Foulkes (1986), effective HRM does not stand alone, but it must be integrated with the overall strategy and performance of an organization. Previous studies documented significant linkages between the use of effective HRM and firm performance in terms of organizational productivity (Schuster, 1983; Guzzo et al., 1985; Katz et al., 1987; Weitzman and Kruse, 1990; Cutcher-Gershenfeld, 1991) and employee turnover (Arnold and Feldman, 1982; Baysinger and Mobley, 1982; Cotton and Tuttle, 1986). Zakat institutions manage religious obligatory alms within the ambit of the Sharī'ah (Islamic law) and social finance. Although they are not profit-oriented, they need to have a comprehensive understanding of how proper management of human capital may contribute toward enhanced administration of zakat.

There are extensive discussions among researchers on how HRM practices differ across jurisdictions and types of organizations, for example, for-profit organizations, non-profit organizations and public institutions. However, studies on distinct features of HRM of zakat institutions are almost non-existent in the literature. To fill this gap, discussions pertaining to the key elements of zakat institutions' HRM - including recruitment, selection, performance appraisal, training and development, and compensation - are gathered from the existing literature and other sources of information such as zakat institutions' websites and publications. In addition, six different semi-structured interviews with zakat officers at two zakat institutions in Klang Valley, namely, Pusat Pungutan Zakat Majlis Agama Islam Wilayah Persekutuan (PPZ-MAIWP) and Lembaga Zakat Selangor Majlis Agama Islam Selangor (LZS-MAIS), were conducted to gain further insight on how HRM is practiced at their respective institutions. Therefore, the present study is among the first to describe the key elements of modern HRM practiced by zakat institutions in Malaysia today. The novelty of this study lies in the proposed HRM model applicable to zakat institutions.

The remainder of this paper is structured as follows. The second section explains the typical components of HRM practices from a zakat operations perspective. The third section provides a review of the current HRM model available in the literature. The fourth section presents the proposed HRM model for zakat institutions. The last section concludes the paper.

\section{Important elements in constructing the human resource management model for zakat institutions}

This section discusses the typical components of the HRM framework that can be found in the literature on conventional organizations, namely, recruitment, selection, performance appraisal, training and development and compensation. These are deliberated from the perspective of zakat operations in Malaysia.

\section{Recruitment}

Recruitment involves identifying and attracting potential individuals deemed fit to perform the stipulated job responsibilities to apply for available positions. From a Sharīah point of view, the recruitment process in zakat institutions must be conducted in a fair manner by informing applicants about the true facts relating to the job vacancies in terms of duties and responsibilities, compensation and other employee benefits. This will enable them to assess whether the job requirements suit their skills, capabilities and interests. As highlighted by institutions in

Malaysia

99 
Ali (2005), the act of specifying job or task requirements was practiced by Prophet Muhammad (peace be upon him) when selecting qualified personnel for leadership positions. With regard to compensation, it must be made known to the applicant, based on the hadìth narrated by Abū Dharr al-Ghifārī (may Allah be pleased with him) in which Prophet Muhammad (peace be upon him) said, "Whoever believes in God and the Day of Judgment should not employ a worker until he or she knows what he or she is going to receive." In investigating the practice of zakat management in Brunei Darussalam, Abdullah (2010) suggested that the recruitment of eligible staff, social workers and volunteers should be done by an HRM and training division established by zakat institutions. He added that the HRM function established at zakat institutions must thoroughly seek out suitable candidates for 'ammil (zakat collector and distributor) and managerial positions who are deemed fit and capable of delivering the assigned duties and responsibilities.

In respect of recruiting for 'âmil positions in Malaysia, a state's zakat institution under the supervision of the State Islamic Religious Council (SIRC) may appoint an individual or institution that will be responsible for collecting and distributing zakat. An individual 'âmil is appointed based on the recommendation made by the mosque committee in every district (Ab Rahman, 2014). The 'âmils appointment can be done on a permanent or seasonal basis such as the appointment of 'ämil for collecting zakăh al-fitr (charity given to the poor during the fasting month). The appointment of an institutional ' $\bar{a}$ mil, on the other hand, is done for the purpose of facilitating zakat institutions collection and distribution of zakat in specific industries with a bigger capacity and vast number of asnāf (zakat beneficiaries). For instance, Lembaga Zakat Selangor (LZS) appointed several local universities - including the International Islamic University Malaysia (IIUM), Universiti Kebangsaan Malaysia (UKM), Universiti Putra Malaysia (UPM), Universiti Teknologi Mara (UiTM) - as 'ammil for higher educational institutions in 2012 for a period of five years. This is to facilitate zakat collection and distribution among university workers and students by opening zakat payment counters and providing advisory and consultancy services.

\section{Selection}

Ali (2005) argues that selection is one of the most difficult tasks in the recruitment of employees. The process involves the screening of numerous applicants for available positions. Notwithstanding that, the Qur'ān has specified the criteria that can be used in selecting a suitable job candidate, namely competence and honesty, as follows:

One of the women said, 'Father, hire him: a strong, trustworthy man is the best to hire' (Qur'ān, 28:26).

Letting favoritism and nepotism influence selection decisions is strictly discouraged from a Shari' ah perspective. In selecting the 'ammil, zakat institutions must ensure that the eligible candidate is a Muslim and has competence or is a faqih (knowledgeable person). Selecting a competent ' $\bar{a}$ mil is certainly not a task that should be taken for granted by zakat institutions as its importance was highlighted by Prophet Muhammad (peace be upon him). For instance, Sayyidina Mu'ādh ibn Jabal (may Allah be pleased with him) was tested by the Prophet (peace be upon him) on his understanding and knowledge before he was sent to Yemen as the governor and 'amil for zakat there. Other 'ummāl (pl. of 'ámil) appointed by the Prophet (peace be upon him) who were well known for their knowledge include 'Umar ibn al-Khattậa and Abū Hurayrah (may Allah be pleased with them).

Selecting an 'âmil who is honest and fair in handling zakat affairs is crucial to avoid fraud and corruption in zakat collection and distribution. In fact, fraudulent behavior by the 'amil may damage public trust and perception of zakat institutions. Seeing these as potential 
threats for zakat institutions, Prophet Muhammad (peace be upon him) strictly prohibited the 'amil from receiving gifts in any form from zakat payers. Also, Sayyidina 'Umar ibn alKhattāb (may Allah be pleased with him) ordered the collection, distribution and administration of zakat to be institutionalized so that the workers for zakat received a fixed amount of income.

Next, the code of ethics for the 'amil, as proposed by Hashim et al. (2011) may serve as a guideline in selecting competent and ethical 'ummāl. The proposed criteria of an ethical 'âmil can be divided into two:

(1) basic principles mentioned in the Qur'ān and Sunnah such as Islam, imān (faith), taqwā (fear of Allah) and $i h s \bar{a} n$ (righteousness); and

(2) a conventional code of ethics adopted by zakat institutions that is aligned with Sharīa principles such as integrity, objectivity, competence, confidentiality and professional conduct.

\section{Performance appraisal}

According to Dessler (2008), performance appraisal is a process of setting work standards, assessing employees' performance and providing them with constructive feedback for motivation and individual development purposes. This process also deals with all sorts of rewards and punishments, which are identified as the most important elements influencing employees' motivation and shaping their work attitudes and behavior. Rewards and punishments in the worldly life and the Hereafter are undoubtedly recognized in Islam as mentioned in the Qur'ān:

We shall punish those who have done evil, and when they are returned to their Lord He will punish them [even more] severely, while those who believed and did good deeds will have the best of rewards: we shall command them to do what is easy for them (Qur'ān, 18:87-88).

Hasan al-Banna et al. (2013) opined that performance appraisal of employees should not be done by zakat institutions merely in the form of monetary rewards. Instead, other forms of employee performance appraisal must also be considered such as giving credit and appreciation for employee contributions (Abdullah et al., 2008) and granting employees a greater level of participation in the decision-making process (Ang, 2002). These will result in better employee satisfaction with zakat institutions. Moreover, previous studies argued that in working environments where there are effective incentive schemes and greater opportunities to participate, employees seem motivated to perform their tasks as ibādah (acts of worship), believing that their good deeds will be rewarded in the worldly life and the hereafter, rather than aiming solely to increase their personal wealth (Hassan, 1985; Basir et al., 2010). This aligns with the concept of rewards and punishments articulated in the Qur'ān, as follows:

And for all are degrees from what they have done. And your Lord is not unaware of what they do (Qur'ān, 6:132).

O mankind, indeed you are labouring toward your Lord with [great] exertion and will meet it (Qur'ān, 84:6).

In addition, effective performance appraisal schemes may contribute towards employee retention with a lower rate of employee turnover recorded by zakat institutions per annum. Failure to offer attractive rewards and provide opportunities to get involved in higher-level decision-making processes may force zakat institutions to bear the huge cost of recruiting 
new staff as well as training and developing new talents in the industry (Fesharaki and Sehhat, 2018).

\section{Training and development}

Employee training involves efforts to develop desirable qualities among employees to increase their level of productivity, hence enabling them to contribute more to an organization's goal attainment. In the case of zakat institutions, adequate training and development programs help 'ummāl, zakat officers, managers and other zakat stakeholders to improve their knowledge and skills pertaining to zakat and other aspects of life. The acquired skills and knowledge then enable them to manage the collection and distribution of zakat in a fair and effective manner and spread the awareness of zakat payment to the public. Therefore, provision of training and development has become the ultimate priority in today's administration of zakat institutions. For instance, the Melaka Zakat Centre (Pusat Zakat Melaka - PZM) implemented the Quality Management System Model (MS 1900) in 2005, in which it specified provision of employee training and development courses as part of its quality objectives and policies (Hasan al-Banna et al., 2013). Over time, the PZM is continuing to allocate adequate funds to conduct a series of training. It is providing facilities and infrastructure and creating a conducive working environment for its workers to enhance their knowledge and skills as well as boost their morale. Moreover, the PZM aims to cultivate a positive work culture by targeting several attitudes and qualities to be developed among their employees. These targeted attitudes include, among others, amanah (trustworthiness), vision, cooperation, openness and akhtāq (good character). To achieve this, apart from competence training programs, the HRM of the PZM also puts emphasis on the insaniyyah or "soft" aspects of management through recitation of the Holy Qur' ān in the morning before the commencement of work and organizing religious speeches and seminars. This is indeed aligned with the concept of tawhìd (full submission to Allah), which becomes the basis for the implementation of the MS 1900.

\section{Compensation}

Compensation comprises direct or indirect forms of incentives provided to employees for their services and contributions made in achieving corporate objectives. In Islam, workers must be given reasonable wages commensurate with the quantity and quality of their work, depending on the current economic situation and cost of living in the society (Beekun, 1996; Ahmad, 1995; Ali, 2005). Besides, Islam strictly prohibits any form of coercion and forced labor (Hashim, 2009) as mentioned in the following Prophetic hadith, narrated by Abu Hurayrah (may Allah be pleased with him):

God says that I will act as a plaintiff on the Day of Judgment against the person who engages some worker on work and takes full work from him but does not give him [full] wages (Sahih Bukhari, Volume 3:34:430).

Giving full recognition to a person's workmanship was highly encouraged as the Prophet (peace be upon him) said in the hadìth narrated by Miqdām:

Nobody has ever eaten a better meal than that which one has earned by working with one's own hands (Sahih Bukhari, Volume 3:34:286).

Regarding the compensation given to the 'amil of zakat, the majority of Sharî'ah scholars have agreed that an adequate amount of remuneration or compensation must be given to those who actively manage zakat affairs, based on the cost that they have incurred in performing their duties and based on the amount required to fulfill their basic necessities 
(Amran and Auzair, 2017). These costs include traveling expenses, maintenance of office and vehicle, utilities, and research and development (R\&D) expenses, among others. However, scholars have different opinions regarding the amount of compensation that should be allocated for the 'amil and where it should be derived from. For example, Imam Shāfi ' 1 allows for $1 / 8$ of the total zakat collected to be given to the 'ummāl, while Imam Abū Hanifah sets a maximum limit of half of the zakat amount collected to be used for 'amil compensation. Imam Shāfi ' 1 's point of view on this matter has been adopted by the majority of states in Malaysia. In the event of insufficient funds to compensate the 'amil or fund zakat activities, the majority of scholars have agreed that the local government shall be responsible to pay remunerations to 'amil using the Treasury's money.

To conclude, managing the 'a mil's compensation is very crucial to ensure the efficiency of the zakat system. Insufficient or late payment made to the 'ummāl may force them to find other side jobs to make extra income to pay their daily expenses. This will adversely shift their focus and time allocated to zakat activities.

\section{A critical review on the existing HRM models}

This section provides a critical review of the existing models of HRM which could be potentially adopted by zakat institutions in Malaysia. One of the earliest attempts to develop a comprehensive model for managing human capital can be traced back to the beginning of the 1980s when Miles and Snow (1984) promulgated the idea of strategy typology (e.g. Defenders, Prospectors, Analyzers and Reactors). This classical perspective on HRM, which was later recognized as a contingency approach, emphasized the ways to achieve a fit between human resources' activities and desired strategic outcomes. In other words, it suggested that an organization adopt a particular set of HRM practices depending upon its organizational strategy formulation. Figure 1 illustrates the contingent relationships of HRM.

Lengnick-Hall and Lengnick-Hall (1988) further developed this contingency approach by observing that a good fit between an organization's business strategy and its HRM is not always desirable. They proposed reciprocal interdependence between corporate strategy and HRM by which human resources are incorporated in both strategy formulation as well as strategy implementation. It is argued that "firms that engage in a strategy formulation process that systematically and reciprocally considers human resources and competitive strategy will perform better" (Lengnick-Hall and Lengnick-Hall, 1988, p. 468). The contingency perspective on HRM has been continuously enriched by other researchers including Jackson and Schuler (1995), who documented empirical findings on the relationship between HRM practices and important components of internal and external organizational environments. The internal components include technology, structure, size, life cycle stages and business strategy. The external components include legal, social and political factors, labor market conditions, industry characteristics and local culture. In

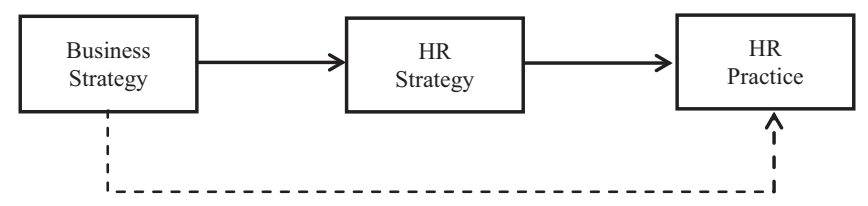

Figure 1.

The contingent

Source: Brewster (1993) relationships of HRM 
$\mathrm{IJIF}$

104

addition, Milliman et al. (1991) extended the "fit" concept within the context of international HRM into four types of fit:

(1) fit between the international HRM functions and the organizational life cycle stage;

(2) fit internally within various human resource functions;

(3) fit between the human resource practices and the firm's cross-national and crosscultural environment and;

(4) fit between the human resource functions of the corporate and foreign subsidiary levels.

As for zakat institutions, it is much more important for the management to ensure that their human resource strategies are aligned with both strategic zakat collection and distribution objectives. This is after taking into consideration internal characteristics, which may vary across zakat institutions such as business complexity, organizational structure, and number of employees, among others. Meanwhile, it is also crucial for zakat managers to acknowledge the influences of external events on the adoption of HRM practices by zakat institutions including issuance of new fatwas (legal opinions), technological advances and political changes.

As the HRM field continues to expand, an extensive series of discussion is beginning to take place among scholars with regard to the development of HRM models in different settings. These include the differences in application of HRM among public, non-profit and private organizations as well as the gap between the USA (US) and European models and the East Asian model of HRM. Rodwell and Teo (2004), who studied the adoption of strategic HRM by for-profit and non-profit knowledge-intensive health services organizations in Australia, found that strategic HRM is significantly and positively related to organizational performance for both types of organizations. It is also found that commercialization or corporatization of public organizations has resulted in a greater adoption of strategic HRM (Teo, 2000; Wei and Lau, 2005). In a similar vein, more corporatized zakat institutions in states such as Selangor, Wilayah Persekutuan, Penang and Sabah have adopted their own HRM models than have the state-administered zakat institutions. Various HRM models for non-profit organizations are discussed in the literature, among others, Ridder and McCandless's (2010) analytical framework of HRM in non-profit organizations, as illustrated in Table I. The analytical framework suggests different HRM strategies,[1] namely, administrative HRM, motivational HRM, strategic HRM and values-driven HRM, depending upon the level of strategic orientation and human resource base in that particular non-profit organization.

In terms of demographic differences, Zhu et al. (2007) explained the gap that exists in the people-management system (PMS) between East Asia, the US and Europe using the triangle influence, as illustrated in Figure 2. While there were strong foreign influences, especially in the case of the USA, through foreign direct investment activities and management education, the East Asian PMS is more characterized by the state to the extent that the PMS

Table I.

The analytical framework of HRM in non-profit organizations
Human resource base

High
Low
Motivational HRM

Administrative HRM

Low
Values-driven HRM

Strategic HRM

High

Strategic orientation

Source: Ridder and McCandless (2010) 


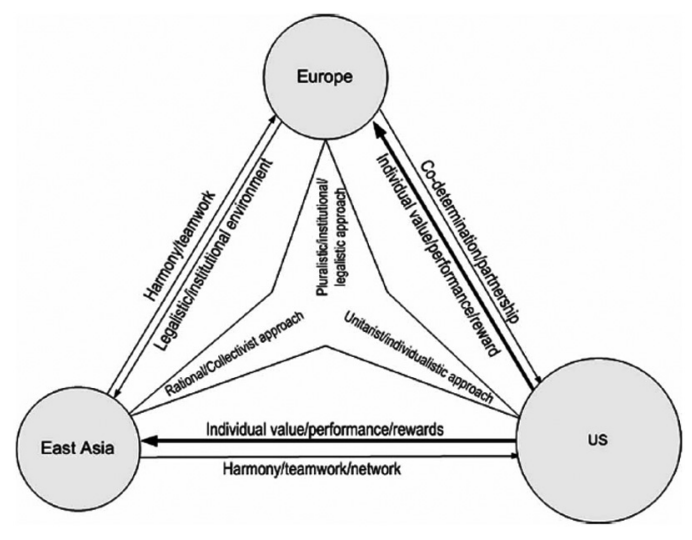

\section{Zakat institutions in Malaysia}

Source: Zhu et al. (2007)

Figure 2. Triangle influence of people-management system between East

Asia, the USA and

Europe

is heavily linked with the state policy on industrial relations and labor market regulations. Being labelled as "the state-led development" model, the PMS in East Asia has undergone a series of reforms and retrenchments over the last few decades. For example, the East Asian PMS transformed from "pro-capital" to "pro-labor" in the late 1980s as part of the democratization movement and converted to "pro-capital" once again after the 1997 Asian Financial Crisis when there were rising cases of unemployment.

The PMS in East Asia is also highly dependent on a functional social and institutional framework, which comprises education, income distribution and awareness of citizenship and legal rights. Apart from that, history plays a significant role in shaping both individual and organizational behavior. Hence, the development of HRM policies in East Asia is usually influenced by the historical backgrounds and norms in a particular organization. For example, the practice of military-oriented management and family traditions in the workplace are commonly found in East Asian countries like Taiwan, Vietnam, Malaysia and Thailand. These distinct features of the East Asian PMS as described by Zhu et al. (2007) are highly relevant to the HRM practice in the Malaysian zakat institutions. State governments exert significant influence, by virtue of the SIRC, in constructing the institutions' strategic visions and policies including those related to human resources.

\section{Proposed human resource management model for zakat institutions}

This section presents a proposed model which could be a useful reference for many zakat institutions in Malaysia in enhancing their HRM practices, as shown in Figure 3.

Zakat institutions are able to design their own human resources strategy by referring to certain principles implied in the proposed HRM model as follows:

- Recruitment, selection, performance appraisal, training and development and compensation are integral parts of the human resource system whereby they often succeed one another. For example, without a proper recruitment process for identifying zakat talents with great potential, selecting "fit and proper" candidates for vacant positions at zakat institutions would be a difficult task.

- Zakat collection and distribution goals and zakat management strategy would serve as parameters in designing the human resources strategy of zakat institutions. In other words, all efforts to enhance zakat talent management must be aligned with 


\section{IJIF \\ 11,1}

106

Figure 3.

Proposed HRM model for zakāh institutions

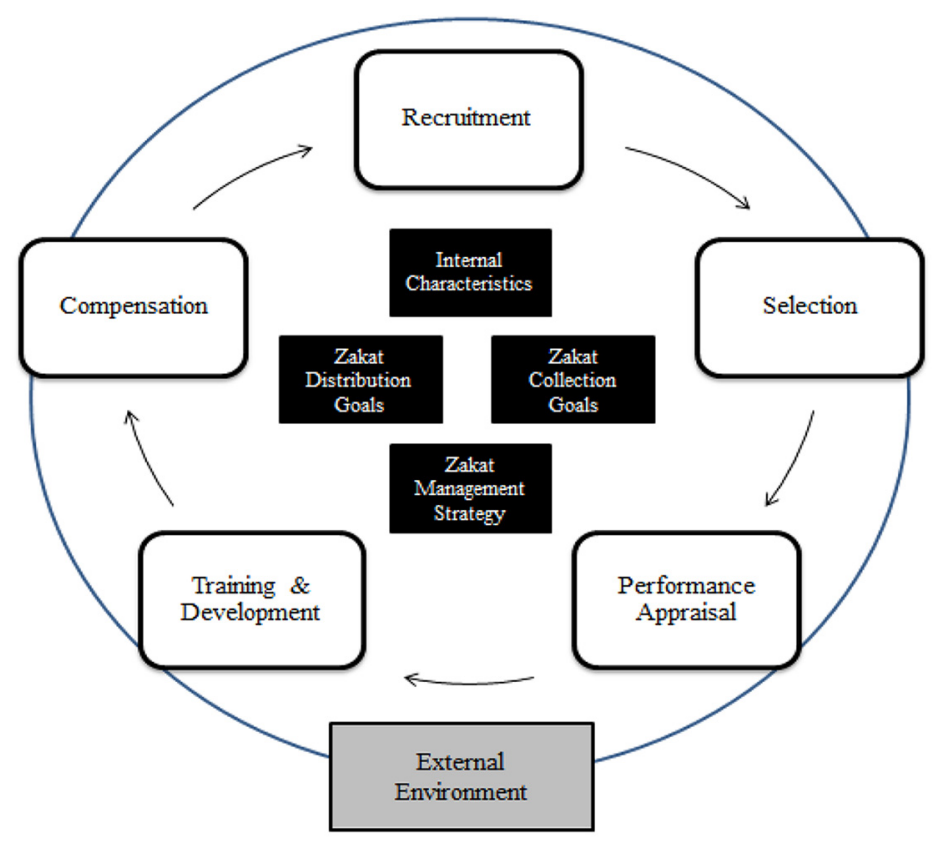

Source: Authors' own

achieving the ultimate goals and objectives of zakat institutions. Besides, human resources strategy must be unique and dynamic in the sense that it suits the specific needs and internal characteristics of each zakat institution such as size, employee turnover, demographic values and social norms.

- Zakat institutions must also acknowledge the significant influence of the external environment, e.g. alteration of laws and regulations and economic conditions, on their human resources system. Development of more resilient and sustainable human resources strategies must be promoted at the level of zakat institutions.

\section{Conclusion}

The purpose of this study is to thoroughly review the current human resource practices of zakat institutions in Malaysia in relation to the key elements of HRM that exist within Islamic organizations as proposed by Hashim (2009) including recruitment, selection, performance appraisal, training and development and compensation. It is strongly recommended for zakat institutions in Malaysia to ensure that their HRM practices correspond with zakat collection and distribution goals, as well as zakat management objectives in general. Besides, the human resources strategy in zakat institutions must be designed in ways that suit the institutions' internal characteristics and specificities of their operations, activities and affairs. Finally, the HRM system in zakat institutions must be adaptive to changes that occur within their external environment such as alteration of labor laws and different economic cycles. The major contribution of this paper would be to assist 
the Malaysian SIRC in formulating a human resources strategy at their respective zakat institutions by referring to the proposed HRM model.

\section{Zakat institutions in Malaysia}

\section{Note}

1. Administrative HRM is adopted when there is no synergistic relationship to the existing HR practices or the organizational strategy (Parry et al., 2005); motivational HRM is adopted when the employees in the non-profit sector appear to have different needs and motivations other than monetary forms (Borzaga and Tortia, 2006); strategic HRM is adopted when the non-profit organization is mainly driven by its strategic goals fueled by the organization's mission and value (Ridder and McCandless, 2010); values-driven HRM is adopted when both non-profit organizations' strategies and human resources are driven by their organizational goals and values.

\section{References}

Ab Rahman, A. (2014), Modul Pengurusan Amil Zakat Malaysia, Universiti Sains Islam Malaysia (USIM), Nilai, Negeri Sembilan.

Abdullah, R. (2010), "Zakat management in Brunei Darussalam: a case study", paper presented at the Seventh International Conference-The Tawhidi Epistemology: Zakat and Waqf Economy, 6-7 January, Bangi.

Abdullah, M.M., Uli, J. and Tari, J.J. (2008), “The influence of soft factors on quality improvement and performance: perceptions from managers", The TQM Journal, Vol. 20 No. 5, pp. 436-452.

Ahmad, M. (1995), Business Ethics in Islam, The International Institute of Islamic Thought, Islamabad.

Ali, A. (2005), Islamic Perspectives on Management and Organization, Edward Elgar, Northampton.

Amran, N. and Auzair, S.M. (2017), "Incentive compensation, organizational commitment and managerial performance in zakat institutions", Terengganu International Finance and Economics Journal (TIFEJ), Vol. 3 No. 2, pp. 50-58.

Ang, A. (2002), "An eclectic review of the multidimensional perspectives of employee involvement", The TQM Magazine, Vol. 14 No. 3, pp. 192-200.

Arnold, H.J. and Feldman, D.C. (1982), "A multivariate analysis of the determinants of job turnover", Journal of Applied Psychology, Vol. 67 No. 3, pp. 350-360.

Basir, S.A., Che Pa, B. and Raja Sulong, R.H. (2010), "Suntikan nilai-nilai Islam ke atas perlaksanaan penambahbaikan berterusan dalam konteks sistem pengurusan kualiti (SPK) ISO 9000”, Jurnal Syariah, Vol. 18 No. 1, pp. 91-122.

Baysinger, B.D. and Mobley, W.H. (1982), "Employee turnover: individual and organizational analyses", available at: www.researchgate.net/publication/235073049_Employee_Turnover_Individual_and_ Organizational_Analyses (accessed 15 March 2017).

Beekun, R.I. (1996), Islamic Business Ethics, The International Institute of Islamic Thought, Herndon, VA.

Borzaga, C. and Tortia, E. (2006), "Worker motivations, job satisfaction, and loyalty in public and nonprofit social services", Nonprofit and Voluntary Sector Quarterly, Vol. 35 No. 2, pp. 225-248.

Boudreau, J.W. (1991), "Utility analysis in human resource management decisions", in Dunnette, M.D. and Hough, L.M. (Eds), Handbook of Industrial and Organizational Psychology, 2nd ed., Vol. 2, pp. 621-745, Consulting Psychology Press, CA.

Brewster, C. (1993), "Developing a 'European' model of human resource management”, International Journal of Human Resource Management, Vol. 4 No. 4, pp. 765-784.

Cotton, J.L. and Tuttle, J.M. (1986), "Employee turnover: a Meta-analysis and review with implications for research", The Academy of Management Review, Vol. 11 No. 1, pp. 55-70. 
Cutcher-Gershenfeld, J. (1991), "The impact on economic performance of a transformation in workplace relations", Industrial and Labor Relations Review, Vol. 44 No. 2, pp. 241-260.

Dessler, G. (2008), Human Resource Management, Prentice-Hall, Englewood Cliffs, NJ.

Fesharaki, F. and Sehhat, S. (2018), "Islamic human resource management (iHRM) enhancing organizational justice and employees' commitment: case of a qard al-Hasan bank in Iran”, Journal of Islamic Marketing, Vol. 9 No. 1, pp. 204-218.

Foulkes, F.K. (1986), Strategic Human Resources Management: A Guide for Effective Practice, Prentice Hall, NJ.

Guzzo, R.A., Jette, R.D. and Katzell, R.A. (1985), "The effects of psychologically based intervention programs on worker productivity: a Meta-analysis", Personnel Psychology, Vol. 38 No. 2, pp. 275-291.

Hasan al-Banna, A.S., Ab. Ghani, A.M. and Basir, S.A. (2013), "Sistem pengurusan islam yang berkualiti mampu menjamin kepuasan pekerja: suatu realiti dan cabaran masa hadapan", Global Journal Al-Thaqafah, Vol. 3 No. 1, pp. 67-84.

Hashim, J. (2009), "Islamic revival in human resource management practices among selected Islamic organisations in Malaysia”, International Journal of Islamic and Middle Eastern Finance and Management, Vol. 2 No. 3, pp. 251-267.

Hashim, A., Saad, R.A.J., Hussain, M. and Hairi, M. (2011), Kod Etika 'āmil Zakāh: Satu Cadangan, Universiti Utara Malaysia, Kedah.

Hassan, M.A. (1985), "Pengurusan, pentadbiran dan kepemimpinan dalam pembinaan tamadun manusia”, paper presented at the Seminar Pentadbiran Islam Peringkat Kebangsaan, 9-10 March, UKM, Bangi.

Jackson, S.E. and Schuler, R.S. (1995), "Understanding human resource management in the context of organizations and their environments", Annual Review of Psychology, Vol. 46 No. 1, pp. 237-264.

Jones, G.R. and Wright, P.M. (1992), "An economic approach to conceptualizing the utility of human resource management practices", Research in Personnel and Human Resources Management, Vol. 10, pp. 271-299.

Katz, H.C., Kochan, T.A. and Keefe, J.H. (1987), "Industrial relations and productivity in the US automobile industry", Brookings Papers on Economic Activity, Vol. 3, pp. 685-727.

Lengnick-Hall, C.A. and Lengnick-Hall, M.L. (1988), "Strategic human resources management: a review of the literature and a proposed typology", Academy of Management Review, Vol. 13 No. 3, pp. 454-470.

Miles, R.E. and Snow, C.C. (1984), "Designing strategic human resources systems", Organizational Dynamics, Vol. 13 No. 1, pp. 36-52.

Milliman, J., Von Glinow, M.A. and Nathan, M. (1991), “Organizational life cycles and strategic international human resource management in multinational companies: implications for congruence theory”, Academy of Management Review, Vol. 16 No. 2, pp. 318-339.

Parry, E., Kelliher, C., Mills, T. and Tyson, S. (2005), "Comparing HRM in the voluntary and public sectors", Personnel Review, Vol. 34 No. 5, pp. 588-602.

Ridder, H.G. and McCandless, A. (2010), "Influences on the architecture of human resource management in nonprofit organizations: an analytical framework", Nonprofit and Voluntary Sector Quarterly, Vol. 39 No. 1, pp. 124-141.

Rodwell, J.J. and Teo, S.T. (2004), "Strategic HRM in for-profit and non-profit organizations in a knowledge-intensive industry: the same issues predict performance for both types of organization", Public Management Review, Vol. 6 No. 3, pp. 311-331.

Schuster, M. (1983), "The impact of union-management cooperation on productivity and employment", Industrial and Labor Relations Review, Vol. 36 No. 3, pp. 415-430. 
Teo, S. (2000), "Evidence of strategic HRM linkages in eleven Australian corporatized public sector organizations", Public Personnel Management, Vol. 29 No. 4, pp. 557-574.

Wei, L.Q. and Lau, C.M. (2005), "Market orientation, HRM importance and competency: determinants of strategic HRM in Chinese firms", The International Journal of Human Resource Management, Vol. 16 No. 10, pp. 1901-1918.

Weitzman, M. and Kruse, D. (1990), Profit Sharing and Productivity, Brookings Institution, Washington, D.C.

Zhu, Y., Warner, M. and Rowley, C. (2007), "Human resource management with 'Asian’ characteristics: a hybrid people-management system in East Asia", The International Journal of Human Resource Management, Vol. 18 No. 5, pp. 745-768.

\section{About the authors}

Aznan Hasan is a member of the Securities Commission Malaysia's Shariah Advisory Council and an Associate Professor at the IIUM Institute of Islamic Banking and Finance. He serves as the Chairman of the Shariah Committee of Maybank Islamic.

Rusni Hassan, PhD, is a Professor at the IIUM Institute of Islamic Banking and Finance. She serves as a member of Shariah Committee of Hong Leong Islamic Bank.

Engku Rabiah Adawiah Engku Ali, PhD, is a Professor at the IIUM Institute of Islamic Banking and Finance. Currently, she is a member of the Shariah Advisory Council of Bank Negara Malaysia (Central Bank of Malaysia), Securities Commission Malaysia and Labuan Financial Services Authority (Labuan FSA), Employees Provident Fund (EPF) and an Independent Shariah Advisor for Islamic securities (șukuk) issuance, approved by and registered with the Securities Commission Malaysia.

Engku Muhammad Tajuddin Engku Ali, PhD, is an Associate Professor at Universiti Sultan Zainal Abidin (UniSZA). He serves as Member of the Shariah Committee of Kuwait Finance House (Malaysia) Berhad. He is also a member of the Shariah Committee, Department of Finance and Banking, Faculty of Business Management and Accounting, UniSZA.

Muhamad Abduh, PhD, is an Assistant Professor at the School of Business and Economics (UBDSBE), Universiti Brunei Darussalam, Brunei.

Nazrul Hazizi Noordin is a $\mathrm{PhD}$ candidate at the International Centre for Education in Islamic Finance (INCEIF), Malaysia. Nazrul Hazizi Noordin is the corresponding author and can be contacted at: hazizinoordin@gmail.com

For instructions on how to order reprints of this article, please visit our website: www.emeraldgrouppublishing.com/licensing/reprints.htm Or contact us for further details: permissions@emeraldinsight.com 